\title{
Spear leaf in determining the harvest timing of peach palm heart
}

\author{
Valéria A Modolo1 ${ }^{\mathbb{D}}$; Larissa do N Ferreira ${ }^{1} \mathbb{D}$; Sandra H Spiering ${ }^{1} \mathbb{D}$; Norma M Erismann² ${ }^{\mathbb{D}}$
}

${ }^{1}$ Instituto Agronômico, Centro de Horticultura, Campinas-SP, Brasil; vamodolo13@gmail.com; ${ }^{2}$ Instituto Agronômico, Centro de Ecofisiologia e Biofísica, Campinas-SP, Brasil; normaeri@iac.sp.gov.br

\begin{abstract}
The harvest timing of peach palm stems for heart-of-palm production is mainly defined by the height and diameter of the stem. Spear leaf parameters could be used in the field to obtain a higher heart-of-palm yield. The aim of this study is to verify if the length and opening of the spear leaf are related to the peach palm heart production. Three harvests were carried out in Campinas (SP), over a period of one year. Before harvest the plants were measured: main stem circumference, height, number of tillers and leaves, length and degree of spear leaf opening. After stem harvest, heart-of-palm production was evaluated. Regardless of the harvest date, the length of the first-rate heart-of-palm was longer when the spear leaf was open. Total mass production of heart-of-palm as a function of spear leaf opening is variable and dependent on weather conditions. When there was a difference in total mass production, this was higher when spear leaf was open. There was no correlation between spear leaf length and total heart-of-palm production. Although there may be an increase in the number of stalks, this had not resulted in a significant effect in terms of mass. The insertion of the spear leaf openness criterion in the determination of the harvest timing may not be worthwhile, since the payment to the producer occurs on the total mass of first-rate heart-of-palm, which may not be higher due to the degree of spear leaf opening.
\end{abstract}

Keyword: Bactris gasipaes, 'guide leaf', correlation, heart-of-palm production.

\begin{abstract}
RESUMO
Folha flecha na determinação do ponto de colheita de palmito pupunha

O ponto de colheita de hastes de pupunheira para produção de palmito é definido principalmente pela altura e diâmetro da haste. Parâmetros da folha flecha parecem ter potencial para utilização a campo visando maior rendimento de palmito. O objetivo desse estudo é verificar se o comprimento e a abertura da folha flecha estão relacionados com a produção de palmito pupunha. Foram realizadas três colheitas em Campinas-SP em um período de um ano. Antes da colheita as plantas foram mensuradas quanto a circunferência da haste principal, altura, número de perfilhos e de folhas, comprimento e grau de abertura da folha flecha. Após a colheita da haste a produção de palmito foi avaliada. Independentemente da data de colheita o comprimento de palmito de primeira foi maior quando a folha flecha estava aberta. A produção total em massa de palmito em função da abertura da folha flecha é variável e dependente das condições climáticas. Quando houve diferença na produção em massa total, essa foi maior quando a folha flecha estava aberta. Não houve correlação entre comprimento da folha e produção total de palmito. Embora possa ocorrer um aumento no número de toletes obtidos, isso não acarretou efeito significativo em termos de massa. A inserção do critério de abertura de folha flecha na determinação do ponto de colheita pode não ser compensatória, uma vez que o pagamento ao produtor ocorre em massa total de palmito de primeira, que poderá não ser maior em função do grau de abertura da folha flecha.
\end{abstract}

Palavras-chave: Bactris gasipaes, folha guia, correlação, produção de palmito.

\section{Received on February 26, 2020; accepted on September 30, 2020}

$\mathrm{T}^{\mathrm{h}}$ he cultivation of peach palm (Bactris gasipaes) has become an excellent option for heart-of-palm production mainly due to the precocious production; in addition to some unique characteristics of the heart-of-palm of peach palm, which are gradually changing the consumption habits and the ways of marketing this vegetable.

One of the important characteristics of the peach palm is the tillering, which gives the cultivation a characteristic of perennial culture (Bovi, 1998). For heart-of-palm production, the harvesting of the stems in the first cut occurs between eighteen to thirty-six months after planting, depending on the genetic material, climate, soil, cultivation techniques, spacing and fertilization. Due to tillering, after the first cut, heartof-palm production is based on tillers, with subsequent harvests occurring, on average, every eight months (Modolo et al., 2019). According to Silva (2017), the average productivity in Vale do Ribeira, the main producing region of the State of São Paulo, is between 3.1 and 4.2 thousand stems/ha/year, with average stem mass between 0.650 and $0.750 \mathrm{~kg}$ and rate average of $0.8 \mathrm{stems} /$ clump/year.

After stem harvesting, the heartof-palm is divided and classified into different portions and from the yield of these portions depends the amount to be received by the producer. Considering 
that more than $95 \%$ of the produced heart-of-palm is commercialized as canned food, the amount paid to the producer for the stem is directly linked to the yield of heart-of-palm in the industry. The industrialized (canned) heart-of-palm is defined as the final product consisting only of young, unexpanded palm leaves, and the presence of the apical bud and the slightly more developed outer leaf can be admitted, as long as the sheath remains imbricated (Ferreira et al., 1976). The portion called 'first-rate heart-of-palm' or 'cream' is marketed as stalks, which are, by definition of Agência Nacional de Vigilância Sanitária (ANVISA; Resolution RDC $\mathrm{n}^{\circ} 17$, of November 19, 1999), pieces length not exceeding $95 \mathrm{~mm}$. The portion immediately below the apical bud, known as the tender stem or basal portion (stem heart-of-palm), is similar to the first-rate heart-of-palm, but with a different structure and consistency, since it is formed, botanically, by the stem (stipe) of the palm. This portion is sold, predominantly, in parts (chopped into cubes, slices of different thickness, balls, spaghetti or lasagna type). The portion called apical residue or tender leaf can still be used, which consists of the portion above the first-rate heart-ofpalm which, due to the more developed leaves, has different consistency and aspect, being considered, as well as the stipe portion, second-rate heart-of-palm.

According to Anefalos et al. (2015), in order to ensure the minimum expected profitability, all industries in Vale do Ribeira (SP) have adopted a unique method to value the purchase price of heart-of-palm: payment for production income at the factory and not for stem sold. The relation between stalks (firstrate heart-of-palm) and chopped (basal and apical portions), in the case of the peach palm heart, follows the proportion of $30 \%$ and $70 \%$, respectively (Silva, 2017). Thus, the income paid to the producer is given by the proportional sum of the income of the different portions, with the first-rate heart-ofpalm reaching twice the amount paid for the second-rate heart-of-palm (Clement \& Bovi, 2000).

In order to determine the correct timing for harvesting peach palm stems, several studies associate linear measurements of the plant, such as height and diameter of the main stem, as well as leaf length and width, showing positive and significant correlations with heart-of-palm production (Clement et al., 1985; Bovi et al., 1992; Clement \& Bovi, 2000; Ramos et al., 2002; Flori et al., 2004). Based on these results, it is currently adopted, as a practical measure in the field, two variables in determining the adequate harvest timing of peach palm: stipe diameter from 9 to $14 \mathrm{~cm}$ and plant height from 150 to $180 \mathrm{~cm}$ (Bovi, 1998; Neves et al., 2008; Modolo, 2014; Fuzitani et al., 2017). According to Mora-Urpi \& Oquendo (1999) and report by some heart-of-palm producers, a third variable could be adopted: length and opening of the spear leaf. The spear leaf also called 'guide leaf' is the youngest leaf that appears at the apex of the palm and is not yet expanded (Figure 1a). This leaf is easy to see on the palm and if its correlation with heart-of-palm yield is proven, it can be used directly in the field as yet another component for defining the harvest timing for peach palm stems.

The objective of this study is to verify if the length and the opening of the spear leaf are related to the heart-ofpalm production of peach palm, aiming to evaluate the inclusion of this variable as an additional criterion in determining the harvest timing of peach palm stems in the field.

\section{MATERIAL AND METHODS}

The experiment was carried out in an area of $1400 \mathrm{~m}^{2}$ (700 plants) located at the Experimental Center "Fazenda Santa Elisa”, Instituto Agronômico (IAC), Campinas, São Paulo State, Brazil (22 $54^{\prime} \mathrm{S} ; 4^{\circ} 05^{\prime} \mathrm{W}$ and $674 \mathrm{~m}$ altitude). The climate is Cwa, according to Köppen classification, with a warm and rainy season from October to March, with an average air temperature between 22 and $24^{\circ} \mathrm{C}, 1.057 \mathrm{~mm}$ rainfall and a dry season, from April to September, with an average temperature between 18 and $22^{\circ} \mathrm{C}, 325 \mathrm{~mm}$ rainfall, normal annual water surplus of $320 \mathrm{~mm}$ and normal annual water deficit of $14 \mathrm{~mm}$ (Ortolani et al., 1995).

The plant material was composed of spineless peach palms, obtained from seeds of selected progenies from the IAC collection. The seedlings were produced in a protected environment and transplanted to the experimental area in November 2011, in 2 x 1 $\mathrm{m}$ spacing and conducted without tiller management. Irrigation was of the micro aspersion type with one emissor every 2 plants, and was defined based on culture evapotranspiration (ETc) which was estimated using the reference evapotranspiration (ETo) by Penman-Monteith method (Allen et al., 1998), calculated based on the meteorological data of the local station and corrected by the crop coefficient (Kc). The fertilization at planting and production was carried out according to soil analysis and following the recommendation of Modolo (2014). Several harvests were carried out from 2013 with crop at tiller harvest stage for this experiment.

The design was completely randomized, in a factorial scheme considering 3 harvest dates and the opening of the spear leaf: 3 types $(\mathrm{FO}=$ fully open; $\mathrm{SO}=$ starting to open and $\mathrm{C}=$ closed), with number of repetitions $\mathrm{n}>20$, or grouped into 2 types $(\mathrm{FO}+\mathrm{SO})$ and $\mathrm{C}$, with $\mathrm{n}>50$ repetitions. Harvests were carried out on 3 different dates, June 1, 2016, December 16, 2016 and May 19, 2017.

For stem standardization before each harvest, the area was evaluated and the following characters were measured in plants: main stem circumference 10 $\mathrm{cm}$ from the ground; height, measure from the ground to the point between the spear leaf and the youngest leaf and number of tillers. From these data, on each harvest date, stems with a diameter between 10 and $15 \mathrm{~cm}$ and height above $180 \mathrm{~cm}$ were selected, with 167, 147 and 169 stems being harvested in June 2016, December 2016 and in May 2017, respectively. At the time of harvest, the number of leaves from the harvested stem was counted, the length of the spear leaf was measured and its degree of opening was determined as described in Figure $1 b$. 
After harvesting, the crude stem of heart-of-palm or crown shaft (portion between the beginning of the heartof-palm sheath until the insertion of the youngest leaf) were labeled and taken to the laboratory to evaluate the production, obtaining the fresh mass of the portions comprising the heart-ofpalm described in Figure 2: 1) Fresh mass of soft stipe, tender stem or basal part $(\mathrm{g})$ : stipe portion immediately below the meristem, still soft and suitable for consumption (Figure 2a); 2) Fresh mass $(\mathrm{g})$ and length $(\mathrm{cm})$ of firstrate heart-of-palm (Figure 2b); 3) Initial and final diameter $(\mathrm{cm})$ of the first-rate heart-of-palm, measured at the basal and terminal end; 4) Fresh mass of tender leaf (g): apical portion still soft, but not surrounded by leaf sheath (Figure 2c); 5) Total fresh mass (g): the sum of the masses of first-rate heart-of-palm, apical and basal portions of the heart-of-palm.

All data were subjected to analysis of variance and when significance was detected, mean values were compared using the Student-Newman-Keuls test at $5 \%$ probability. Pearson's linear correlation analyzes between the length of the spear leaf and heartof-palm production variables were also performed. The Statgraphics 4.1 Program was used in all statistical analyzes.

\section{RESULTS AND DISCUSSION}

The joint analysis of the three harvest dates (June 2016, December 2016, May 2017) showed significant differences, regarding the spear leaf opening and heart-of-palm production for the following variables: apical mass, first-rate heart-of-palm mass and length (Table 1). There was no difference in the total production of peach palm heart due to the opening of the spear leaf during the harvests, however there was a higher production of first-rate heart-of-palm (stalks) and less apical mass production when the stem was harvested with the spear leaf fully open (FO) or starting to open (SO). There was a significant interaction $(p \leq 0.05)$ between harvests and spear leaf opening for all production variables, with the exception of apical mass.

The lack of studies on harvesting timing of peach palm heart using the

spear leaf as a reference led to pilot (unpublished) experiments to adapt the methodology. In these experiments
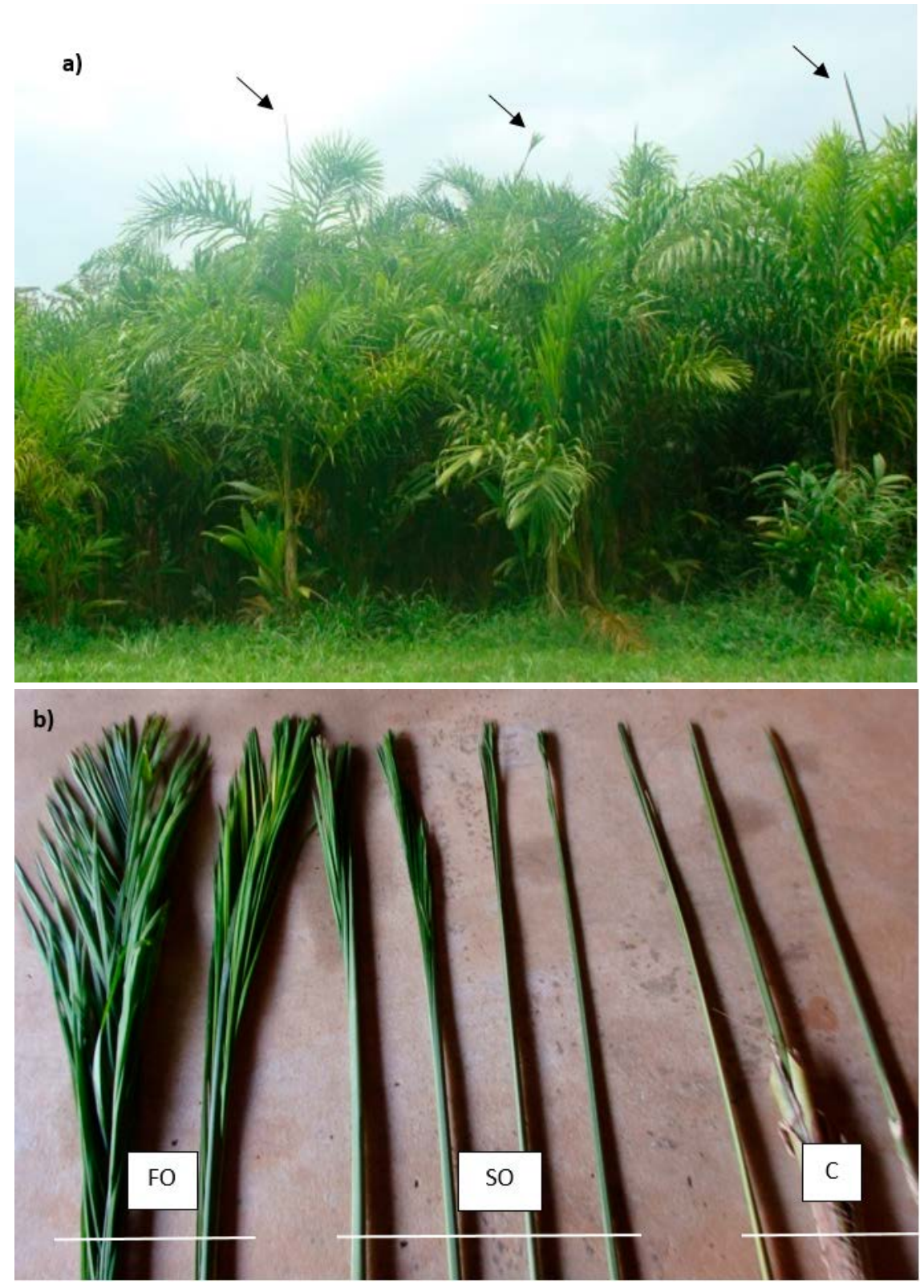

Figure 1. a) Peach palm plantation for the production of heart-of-palm with arrows indicating details of the spear leaf; b) Detail of the opening of the peach palm spear leaf: $\mathrm{FO}=$ fully open; $\mathrm{SO}=$ starting to open; $\mathrm{C}=$ closed. Campinas, Instituto Agronômico, 2020 .

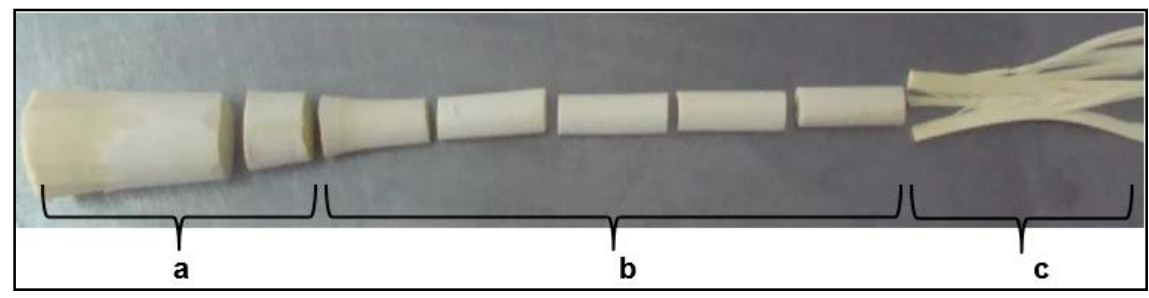

Figure 2. Stem of peach palm without leaf sheaths: a) Tender stem or basal portion; b) Stalks or first-rate heart-of-palm; c) Tender leaf or apical portion. Campinas, Instituto Agronômico, 2020. 
it was found that the definition of the degree of opening of the spear leaf should be carried out at the time of harvest, since the transition of the degree of the spear leaf opening depends on the weather conditions and the growth capacity of the plant, preventing prior marking and adjustment in the number of repetitions per treatment. Thus, the differentiation of the spear leaf in three degrees of openness, as proposed in the methodology, enabled analysis of the experimental data with a number of repetitions that varies considerably per treatment. In the three harvests, the number of stems harvested with the closed spear leaf (C) was always higher. In an area with 700 plants, 167 stems (114 C, 33 SO and 20 FO) were able to be cut in June 2016; in December 2016 there were 147 (64 C, $36 \mathrm{SO}$ and $47 \mathrm{FO}$ ) and 169 stems in May 2017 (81 C, 49 SO and $39 \mathrm{FO}$ ). Adding to this fact the results of Table 1 in which there was no difference in the production of firstrate heart-of-palm and apical portion for both fully open (FO) and starting to open (SO) leaves and considering that in the field it was easier and more practical to differentiate between only closed or open leaf, it was decided to analyze the data with two degrees of spear leaf opening, that is, closed (C) and open (sum of $\mathrm{SO}+\mathrm{FO}$ ). Peach palm is a plant that tillers and there is not always dominance in growth among tillers. In general, in the first cut, there is a mother plant that reaches the size for harvest before its tillers. However, from the second cut, the plant may have a thicket appearance, with several stems overlapping its crowns, which can make

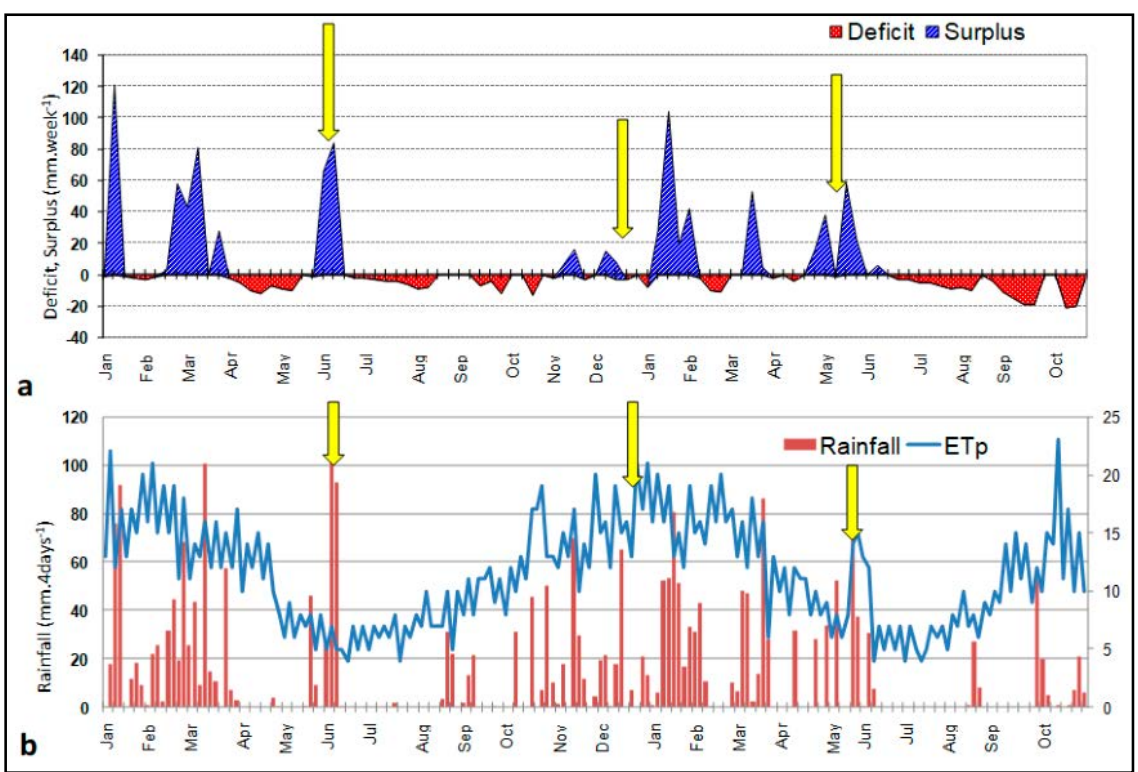

Figure 3. a) Heart-of-palm harvest of peach palm on the water balance graph; b) Evapotranspiration (ETp) and rainfall from January 2016 to October 2017. Campinas, Instituto Agronômico, 2020. Source: IAC Meteorological Stations Network. it difficult to see similar degrees of spear leaf opening.

Considering as factors the three harvest dates (June 2016; December 2016 and May 2017) and two degrees of spear leaf opening, $\mathrm{C}$ and ( $\mathrm{SO}+$ FO) there was no interaction between the harvest dates and the opening of the spear leaf for the biometric variables of the palm, however for the production variables there was significant interaction $(\mathrm{p} \leq 0.05)$ for all variables, except apical mass and length of the first-rate heart-of-palm.

In Table 2 it is observed that in the three harvests there was less apical mass production and greater length of firstrate heart-of-palm when the harvest was made with the stems showing an open spear leaf $(\mathrm{SO}+\mathrm{FO})$, regardless of the harvest season. According to Fuzitane et al. (2017), the spear leaf must be closed or, at the most, starting its opening to obtain a higher yield of whole heart-of-palm (first-rate). The culture variability and the lack of scientific studies in this area can induce some common practices among producers and reported in newsletters that are not always validated experimentally. It is true that in the factory the greater length of the first-rate heart-of-palm can become a greater number of stalks per stem, since for processing there is a cut every $9 \mathrm{~cm}$. In this context, the greater length of the first-rate heart-ofpalm may provide greater utilization of this product, that is, greater yield in the number of stalks/stem. However, the payment to the producer occurs in total mass of first-rate heart-of-palm. For this better use of the first-rate heart-of-palm in the factory, due to the increased length of the heart-of-palm harvested with open

Table 1. Heart-of-palm production of peach palm according to the spear leaf opening. Campinas, Instituto Agronômico, 2020.

\begin{tabular}{|c|c|c|c|c|c|c|c|}
\hline \multirow{3}{*}{ Spear leaf opening } & \multirow{3}{*}{$\begin{array}{c}\text { Total mass } \\
\text { (g) }\end{array}$} & \multirow{3}{*}{$\begin{array}{c}\text { Basal mass } \\
\text { (g) }\end{array}$} & \multirow{3}{*}{$\begin{array}{c}\text { Apical mass } \\
\text { (g) }\end{array}$} & \multicolumn{4}{|c|}{ First-rate heart-of-palm } \\
\hline & & & & \multirow{2}{*}{$\begin{array}{c}\text { Mass } \\
(\mathrm{g})\end{array}$} & \multirow{2}{*}{$\begin{array}{c}\text { Length } \\
\text { (cm) }\end{array}$} & \multicolumn{2}{|c|}{ Diameter (cm) } \\
\hline & & & & & & Initial & Final \\
\hline Closed $(\mathrm{C})$ & $488.2^{\text {ns }}$ & $291.8^{\mathrm{ns}}$ & $36.3 \mathrm{a}$ & $160.5 \mathrm{~b}$ & $25.1 \mathrm{~b}$ & $3.4^{\mathrm{ns}}$ & $2.5^{\mathrm{ns}}$ \\
\hline Starting to open (SO) & 474.3 & 276.1 & $20.5 \mathrm{~b}$ & $177.6 \mathrm{a}$ & $31.6 \mathrm{a}$ & 3.4 & 2.4 \\
\hline Fully open (FO) & 485.3 & 276.4 & $15.8 \mathrm{~b}$ & $193.0 \mathrm{a}$ & $32.5 \mathrm{a}$ & 3.3 & 2.6 \\
\hline $\mathrm{CV}(\%)$ & 15.46 & 18.58 & 65.42 & 19.00 & 14.81 & 5.49 & 6.32 \\
\hline
\end{tabular}

Means followed by different letters in the columns indicate a significant difference by the Student-Newman-Keuls test at 5\% probability; $\mathrm{ns}=$ not significant. $\mathrm{CV}=$ coefficient of variance. For statistical analysis, the original data were transformed into $\sqrt{x+1}$. 
spear leaf $(\mathrm{SO}+\mathrm{FO})$, to be passed on in price to the producer, new payment arrangements should be considered.

There was an interaction between harvest date and spear leaf opening, and only in the harvest of May 2017 there was a higher total production of heart-of-palm on the stems harvested with open spear leaf, possibly due to the higher production of the first-rate heart-of-palm mass. In December 2016 there was a greater production of tender stem (basal mass) when the stem was harvested with closed spear leaf, but there was no significant difference in the total production due to the opening of the spear leaf.

The heart-of-palm can be cut throughout the year, but in the dry season, even in irrigated cultivation, the yield may decrease due to the lower mass of the stems (Bovi, 1998; Modolo, 2014). Despite the fact that the climate in Campinas presents a drier season, from April to September, with temperatures between 18 and $22^{\circ} \mathrm{C}$, it is observed that the harvest at this period (in June 2016 and May 2017) promoted a greater total production of heart-ofpalm (Table 3).
In Figure 3, the dates of harvesting peach palm heart are highlighted in the graph of water balance, evapotranspiration and rainfall from January 2016 to October 2017. The harvests carried out in June 2016 and May 2017 were after a period of greater rainfall and less water deficit and provided greater heart-of-palm production (Table 3). In the December 2016 harvest there was low rainfall and greater soil water deficit, although it was considered the season of greatest production (spring/summer). According to Bovi (1998), since the heart-ofpalm is $90 \%$ water, the highest yield in production occurs when the stem is harvested in the rainy season, both in ideal cultivation areas, such as on the coast and Vale do Ribeira, as well as in regions of the plateau of São Paulo State where irrigation is needed. However, since the region is suitable for cultivation, it can be inferred that what allows higher yield of total heartof-palm is the water state of the soil or atmosphere in the period before the harvest. Studies of gas exchange in peach palms cultivated in Campinas indicated that even under irrigation, plants regulate photosynthesis and water loss through stomatal opening, which responds to environmental conditions such as high temperature and air vapor pressure deficit (Tucci et al., 2010, 2018). As there seems to be interference from the climate in the production of heart-of-palm, there is a need for further work of this influence in regions without water deficit.

Regarding the biometric evaluations of the palm, despite the standardization of the plant's diameter and height, as described in the methodology for establishing the parameters of the stem harvest timing, there were differences among all the variables considering the three harvests (Table 3).

Linear measurements such as height and diameter of the main stem show positive and significant correlations with the production of heart-of-palm in several palms: assai palm (Bovi et al., 1990), peach palm (Bovi et al., 1992; Clement et al., 1996) and King palm (Bovi et al., 2001). According to Clement \& Bovi (2000), the height of the plant is one of the most easily measurable and is highly correlated with the production of heart-of-palm. However, if we consider heart-of-palm

Table 2. Heart-of-palm production of peach palm according to the harvest date and the spear leaf opening: closed (C) and open [sum of starting to open (SO) and fully open (FO)]. Campinas, Instituto Agronômico, 2020.

\begin{tabular}{|c|c|c|c|c|c|c|c|}
\hline \multirow{3}{*}{ Spear leaf opening } & \multirow{3}{*}{$\begin{array}{c}\text { Total mass } \\
\text { (g) }\end{array}$} & \multirow{3}{*}{$\begin{array}{l}\text { Basal mass } \\
\text { (g) }\end{array}$} & \multirow{3}{*}{$\begin{array}{c}\text { Apical mass } \\
\text { (g) }\end{array}$} & \multicolumn{4}{|c|}{ First-rate heart-of-palm } \\
\hline & & & & \multirow{2}{*}{ Mass (g) } & \multirow{2}{*}{$\begin{array}{c}\text { Length } \\
\text { (cm) }\end{array}$} & \multicolumn{2}{|c|}{ Diameter (cm) } \\
\hline & & & & & & Initial & Final \\
\hline \multicolumn{8}{|l|}{ June 2016} \\
\hline Closed (C) & $571.1^{\text {ns }}$ & $336.0^{\mathrm{ns}}$ & 36.5 & $198.6^{\mathrm{ns}}$ & 28.3 & $3.6 \mathrm{a}$ & $2.8 \mathrm{a}$ \\
\hline Open $(\mathrm{SO}+\mathrm{FO})$ & 520.0 & 295.6 & 16.7 & 207.7 & 34.6 & $3.4 \mathrm{~b}$ & $2.7 \mathrm{~b}$ \\
\hline \multicolumn{8}{|l|}{ December 2016} \\
\hline Closed (C) & $429.8^{\text {ns }}$ & $266.3 \mathrm{a}$ & 27.9 & $135.6^{\text {ns }}$ & 23.7 & $3.4^{\mathrm{ns}}$ & $2.2^{\mathrm{ns}}$ \\
\hline Open (SO+FO) & 397.1 & $234.1 \mathrm{~b}$ & 14.4 & 148.5 & 27.9 & 3.2 & 2.3 \\
\hline \multicolumn{8}{|l|}{ May 2017} \\
\hline Closed (C) & $464.8 \mathrm{~b}$ & $273.0^{\text {ns }}$ & 44.4 & $147.4 \mathrm{~b}$ & 24.2 & $3.4^{\mathrm{ns}}$ & $2.5^{\mathrm{ns}}$ \\
\hline Open (SO+FO) & $518.7 \mathrm{a}$ & 298.5 & 26.4 & $193.7 \mathrm{a}$ & 32.3 & 3.5 & 2.6 \\
\hline \multicolumn{8}{|l|}{ Mean } \\
\hline Closed (C) & 488.5 & 291.8 & $36.3 \mathrm{a}$ & 160.5 & $25.4 \mathrm{~b}$ & 3.4 & 2.5 \\
\hline Open (SO+FO) & 477.0 & 276.1 & $19.2 \mathrm{~b}$ & 183.3 & $31.6 \mathrm{a}$ & 3.3 & 2.5 \\
\hline CV $(\%)$ & 15.41 & 18.44 & 60.56 & 19.43 & 15.35 & 5.50 & 6.40 \\
\hline
\end{tabular}

Means followed by different letters in the columns indicate a significant difference by the Student-Newman-Keuls test at $5 \%$ probability; $\mathrm{ns}=$ not significant. $\mathrm{CV}=$ coefficient of variance. For statistical analysis, the original data were transformed into $\sqrt{x+1}$. 
Table 3. Mean values of growth and heart-of-palm production variables of peach palm in three harvest dates. Campinas, Instituto Agronômico, 2020.

\begin{tabular}{|c|c|c|c|c|c|c|c|}
\hline \multirow{2}{*}{ Harvest date } & \multicolumn{7}{|c|}{ Palm growth variables } \\
\hline & \multicolumn{2}{|c|}{ Height (cm) } & \multicolumn{2}{|c|}{ Diameter $(\mathrm{cm})$} & Leaf number & \multicolumn{2}{|c|}{ Tiller number } \\
\hline June 2016 & \multicolumn{2}{|c|}{$225.7 \mathrm{~b}$} & \multicolumn{2}{|l|}{$13.2 \mathrm{a}$} & $5.6 \mathrm{a}$ & \multicolumn{2}{|c|}{$12.3 \mathrm{a}$} \\
\hline December 2016 & \multicolumn{2}{|c|}{$225.8 \mathrm{~b}$} & \multicolumn{2}{|l|}{$12.7 \mathrm{~b}$} & $5.4 \mathrm{~b}$ & \multicolumn{2}{|c|}{$9.7 \mathrm{c}$} \\
\hline May 2017 & \multicolumn{2}{|c|}{$255.2 \mathrm{a}$} & \multicolumn{2}{|l|}{$13.1 \mathrm{ab}$} & $5.8 \mathrm{a}$ & \multicolumn{2}{|c|}{$10.9 \mathrm{~b}$} \\
\hline \multirow{4}{*}{ Harvest date } & \multicolumn{7}{|c|}{ Heart-of-palm production } \\
\hline & \multirow{3}{*}{$\begin{array}{l}\text { Total mass } \\
\text { (g) }\end{array}$} & \multirow{3}{*}{$\begin{array}{l}\text { Basal mass } \\
\text { (g) }\end{array}$} & \multirow{3}{*}{$\begin{array}{l}\text { Apical mass } \\
\text { (g) }\end{array}$} & \multicolumn{4}{|c|}{$\begin{array}{l}\text { First-rate heart-of-palm } \\
\end{array}$} \\
\hline & & & & Mass & Length & Dian & cm) \\
\hline & & & & (g) & $(\mathrm{cm})$ & Initial & Final \\
\hline June 2016 & $538.1 \mathrm{a}$ & $309.6 \mathrm{a}$ & $21.9 \mathrm{~b}$ & $206.6 \mathrm{a}$ & $33.1 \mathrm{a}$ & $3.4 \mathrm{a}$ & $2.7 \mathrm{a}$ \\
\hline December 2016 & $408.3 \mathrm{c}$ & $244.9 \mathrm{c}$ & $18.5 \mathrm{~b}$ & $144.7 \mathrm{c}$ & $26.7 \mathrm{c}$ & $3.2 \mathrm{~b}$ & $2.3 \mathrm{c}$ \\
\hline May 2017 & $501.7 \mathrm{~b}$ & $289.9 \mathrm{~b}$ & $32.2 \mathrm{a}$ & $179.8 \mathrm{~b}$ & $29.6 \mathrm{~b}$ & $3.4 \mathrm{a}$ & $2.5 \mathrm{~b}$ \\
\hline
\end{tabular}

Means followed by different letters in the columns indicate a significant difference by the Student-Newman-Keuls test at $5 \%$ probability. For statistical analysis, the original data were transformed into $\sqrt{x+1}$.

Table 4. Linear correlation between the length of the spear leaf and the heart-of-palm production variables of peach palm. Campinas, Instituto Agronômico, 2020.

\begin{tabular}{|c|c|c|c|c|c|c|c|}
\hline & \multirow{3}{*}{$\begin{array}{c}\text { Total mass } \\
\text { (g) }\end{array}$} & \multirow{3}{*}{$\begin{array}{c}\text { Basal mass } \\
\text { (g) }\end{array}$} & \multirow{3}{*}{$\begin{array}{c}\text { Apical mass } \\
\text { (g) }\end{array}$} & \multicolumn{4}{|c|}{ First-rate heart-of-palm } \\
\hline & & & & \multirow{2}{*}{ Mass (g) } & \multirow{2}{*}{ Length (cm) } & \multicolumn{2}{|c|}{ Diameter } \\
\hline & & & & & & Initial (cm) & Final $(\mathrm{cm})$ \\
\hline Spear leaf $(\mathrm{cm})$ & 0.012 & -0.017 & $-0.269 * *$ & $0.155^{* *}$ & $0.380^{* *}$ & -0.052 & $-0.141 * *$ \\
\hline
\end{tabular}

** Significant at $1 \%$ probability.

production from tillers and not from first cut plants (mother plant) and also a population of highly tillered plants, plant height may not be the most suitable linear measurement for heart-of-palm production. Table 3 shows that both in the highest harvesting of heart-ofpalm production (June 2016) and in the one with lower production (December 2016) there was no difference in plant height. In the third harvest there was an increase in plant height. This result can be explained by the genetic material, as they are improved progenies with an average tillering above 9 tillers/ plant (Table 3). This high tillering can cause an excess of shading promoting an increase in plant height as the crop gets older. Plant diameter is a measurement that is highly correlated with heart-of-palm production (Bovi et al., 1992; Mora-Urpí \& Oquendo, 1999; Yokomizo \& Farias Neto, 2003) and should always be considered to define the stem harvest timing.

Regarding the correlation between spear leaf length and heart-of-palm production, there was no correlation between total heart-of-palm mass and spear leaf length (Table 4). The highest linear correlation observed between the length of the spear leaf and the production variables was obtained with respect to the length of the firstrate heart-of-palm $(r=0.380 ; p \leq 0.01)$. Mora-Urpí \& Oquendo (1999) found a high correlation between spear leaf length and heart-of-palm production, but in this case, it was only considered a closed spear leaf or starting to open. According to these authors, the longer the spear leaf, the greater the heart-ofpalm yield.

The total production of peach palm heart as a function of the spear leaf opening at the time of stems harvesting is variable and appears to be dependent on the climatic conditions prior to the harvest date. When there was a difference in the total production of heart-of-palm, the highest production was obtained when the harvest was carried out with the spear leaf open $(\mathrm{SO}+\mathrm{FO})$. Considering the different portions (basal or tender stem, stalks and tender leaf or apical portion), which make up the total mass of heart-of-palm produced and regardless of the date of harvest, when peach palm stems were harvested with open spear leaf (SO + FO), the length of the first-rate heart-ofpalm was longer. Considering that the heart-of-palm sold in preserves follows an ANVISA standard of $9 \mathrm{~cm}$ in length for commercialization in glass, a longer length of first-rate heart-of-palm/stem provides a greater number of stalks/ plant, and greater use of the first-rate heart-of-palm may occur in the factory.

From a practical point of view, the insertion of the spear leaf opening criterion as an additional factor in determining the harvest timing of peach palm stems in the field may not be compensatory, since it increases the work of the harvester and greater production may not be obtained in terms of heart-of-palm mass. Considering that in the processing factory there may be a higher yield in the number of stalks due to the greater length of the firstrate heart-of-palm harvested with open spear leaf $(\mathrm{SO}+\mathrm{FO})$, this parameter could be included in the harvest, as 
long as the payment arrangement to the producer is reviewed where currently only mass production of heart-of-palm is considered. Also for some markets, such as in natura heart-of-palm, and some production arrangements, for example, when the producer himself performs a more selective harvest, this criterion can be adopted, but in this case stems must be harvested with the spear leaf open $(\mathrm{SO}+\mathrm{FO})$.

\section{ACKNOWLEDGMENTS}

To Conselho Nacional de Desenvolvimento Científico e Tecnológico (CNPq) for the scholarship of the Technological Development Program (PIBITI) to the second author.

\section{REFERENCES}

ALLEN, RG; PEREIRA, LS; RAES, D; SMITH, M. 1998. Crop evapotranspiration: Guidelines for computing crop water requirements. Rome: Irrigation \& Drain. Paper 56. UN-FAO.

ANEFALOS, LC; MODOLO, VA; FUZITANI, EJ. 2015. Perforrmance indexes for the peach palm supply chain. Acta Horticulturae 1103: 25-29.

BOVI, MLA. 1998. Palmito pupunha, Informações Básicas Para o Cultivo. Campinas, Instituto Agronômico, 50p. (Boletim técnico IAC. 173).

BOVI, MLA; GODOY JUNIOR, G; SPIERING, SH; CAMARGO, SB. 1990. Relação entre caracteres da planta e do palmito de açaizeiros. Bragantia 49: 69-81.

BOVI, MLA; SAES, LA; GODOY JUNIOR, G. 1992. Correlações fenotípicas entre caracteres não destrutíveis e palmito em pupunheiras. Turrialba 42: 382-390.

BOVI, MLA; SAES, LA; UZZO, RP; SPIERING, SH. 2001. Adequate timing for heart-ofpalm harvesting in King palm. Horticultura Brasileira 19: 135-139.

CLEMENT, CR; BOVI, MLA. 2000. Padronização de medidas de crescimento e produção em experimento com pupunheiras para palmito. Acta Amazonica 30: 349-462.

CLEMENT, CR; MANSHARDT, RM; De FRANK, J; CAVALETTO, CG; NAGAI, NY. 1996. Introduction of pejibaye for heart-ofpalm in Hawaii. HorsScience 31: 765-768.

CLEMENT, C R; MORA-URPÍ, J; COSTA, SS. 1985. Estimación del área foliar del pejibaye (Bactris gasipaes H.B.K.). Revista de Biologia Tropical 33: 103.112.

FERREIRA, VLP; MIYA, EE; SHIROSE, I; ARANHA, C; SILVA, EAM; HIGHLANDS, ME. 1976. Comparação físico químico organoléptica de palmito enlatado de três espécies de palmeiras. Coletânea do Instituto de Tecnologia de Alimentos 7: 389-416.

FLORI, JE; RESENDE, GM; DRUMOND, MA. 2004. Rendimento da pupunheira em função da densidade de plantio, diâmetro de corte e manejo dos perfilhos no Vale do São Francisco. Ciência Agrotecnologica 28: 70-74.

FUZITANI, EJ; NOMURA, ES; FUZITANI, AS. 2017. Tratos culturais na cultura da pupunha. In: ROZANE, DE; SILVA, CA; FRANCHETTI, M (eds). Palmito pupunha: do plantio a colheita. Registro: UNESP/Campus Experimental de Registro. p.75-85.

MODOLO, VA. 2014. Pupunha. In: AGUIAR, ATDE; GONÇALVEZ, C; PATERNIANI, MEAGZ; TUCCI, MLS; CASTRO, CEFD (eds). Instruções agrícolas para as principais culturas econômicas. 7. a ed. revista e atualizada. Campinas: Instituto Agronômico, p. 329-333. (Boletim IAC, n. ${ }^{\text {o } 200) . ~}$

MODOLO, VA; ANEFALOS, LC; MARTINS, ALM; GALLO, PB; ROJO-VEGA, SM; SAES, LA. 2019. Palmito pupunha: a pesquisa gerando nova opção de agronegócio. $O$ Agronômico 71: 132-143.

MORA-URPÍ, J; OQUENDO, CA. 1999. Cosecha. In: MORA URPÍ, J; GAINZA, EJ (eds). Palmito de pejibaye (Bactris gasipaes Kunth): Seu cultivo e industrialização. FUNDEVI, Univ. Costa Rica, São José. p.118-122.

NEVES, EJM; SANTOS, AF; MARTINS, EG; RODIGHERI, HR; BELLETINI, S; CORRÊA, C. 2008. Manejo da pupunheira (Bactris gasipaes Kunth.) para palmito em áreas sem restrições hídricas. Colombo: Embrapa (Circular Técnica 89).

ORTOLANI, AA; CAMARGO, MBP; PEDRO JR, MJ. 1995. Normais climatológicas dos postos meteorológicos do Instituto Agronômico: 1. Centro Experimental de Campinas, Campinas: Instituto Agronômico. 13p. (Boletim Técnico).

RAMOS, A; BOVI, MLA; FOLEGATTI, MV. 2002. Desenvolvimento vegetativo da pupunheira irrigada por gotejamento em função de níveis de depleção de água no solo. Horticultura Brasileira 20: 28-33.

SILVA, CA. 2017. A Cultura do palmito pupunha e o mercado. In: ROZANE, DE; SILVA, CA; FRANCHETTI, M (eds). Palmito pupunha: do plantio a colheita. Registro: UNESP/Campus Experimental de Registro. p.1-12.

TUCCI, MLS; ERISMANN, NM; MACHADO, EC; RIBEIRO, RV. 2010. Diurnal and seasonal variation in photosynthesis of peach palms grown under subtropical conditions. Photosynthetica 48: 421-429.

TUCCI, MLS; MACHADO, EC; MODOLO, VA; ERISMANN, NM. 2018. Photosynthesis and water relations of peach palms (Bactris gasipaes Kunth) under soil water deficit. Theoretical and Experimental Plant Physiology. 30: 29-39. Available at https:// doi.org/10.1007/s40626-018-0099-0.

YOKOMIZO, GKI; FARIAS NETO, JT. 2003. Caracterização fenotípica e genotípica de progênies de pupunheira para palmito. Pesquisa Agropecuária Brasileira 38: 67-72. Available at https://doi.org/10.1590/S0100204X2003000100009. 